\title{
O índio brasileiro e a Revolução Francesa
}

\author{
Rogério F. Guerra \\ Universidade Federal de Santa Catarina
}

FRANCO, A.A. DE M. O indio brasileiro e a Revolução Francesa. Rio de Janeiro: TopBooks, 2000.

Uuitos eruditos acreditavam que os índios eram criaturas míticas, habitantes de um Éden tropical e dotados de uma bondade natural. O homem primitivo não fora corrompido pelos avanços da civilização e era, portanto, moralmente superior ao europeu. As impressões sobre os índios eram baseados em relados dos exploradores, homens rudes e incultos, $\mathrm{e}$ foram alimentadas por ruminações mentais daquilo que poderíamos designar de "antropologia de gabinete". Acreditava-se que os índios eram fortes e bem nutridos e facilmente chegavam aos 150 anos de idade; eles andavam nus como se fossem os primeiros habitantes da Terra, sem a mácula do Pecado Original. As árvores thes proviam frutos saborosos e suculentos, os rios transbordavam de peixes e animais carnudos praticamente se ofereciam para o abate. O modo de vida tranqüilo e a alimentação farta explicavam o sistema comunal perfeito; não havia espaço para a ganância, inveja e o acúmulo de bens materiais. Anatureza provia tudo.

A idealização da vida selvagem deu origem a equívocos curiosos, como a suposta preocupação com o asseio corporal - os portugueses aprenderam a tomar banho diário com os índios, postulam alguns. Os constantes mergulhos nas águas dos rios indicavam tal preocupação, embora fosse mais adequado explicar o hábito como resultante do forte calor tropical. Por outro lado, os relatos de viagens também descreviam que os índios defecavam dentro das ocas, bebiam água suja dos rios e os descuidos no preparo da alimentação ocasionavam sérias infestações parasitárias. Entretanto, o modo de vida dos índios inspirou vários personagens da literatura infanto-juvenil, como Tarzan, Mogli e Pocahontas. Essas histórias enfatizam a beleza e o suposto relacionamento harmonioso dos índios com os elementos da vida selvagem; eles exibem virtudes como lealdade e honestidade, interagem pacificamente com os animais e se conformam com os humores da "mãe natureza", diferentemente do homem moderno que adapta tais elementos às suas necessidades.

\footnotetext{
1 Endereço para correspondências: Universidade Federal de Santa Catarina, Departamento de Psico-
} logia, Campus Universitário, Florianópolis, SC, 88040-900 (E-mail: rfguerra@cfh.ufsc.br). 


\section{HÜMANAS}

A atitude favorável m relação à natureza e o mito do Éden tropical estão relacionados ao moderno pensamento ecológico. Dentro dessa linha de pensamento, a civilização corrompe o homem e elimina de seu coração suas virtudes originais. Entretanto, parece que os próprios índios não estão convencidos disso, pois eles buscam assistência médica nos postos de saúde, gostam de TV a cabo e se deslocam em camionetes movidas a diesel. Muitas de nossas idéias acerca dos habitantes do Éden tropical resistem ao tempo, mas elas só existem na nossa imaginação.

Em contraste com tais idéias, muitos pensavam que os índios não pertenciam ao gênero humano e encontravam-se no meio do processo evolucionário (meio homem, meio macaco). Alguns acreditavam que o cruzamento entre o homem e o macaco ainda era possível e era esta a explicação para a crença na existência de seres humanos dotados de caudas vistosas, criaturas peludas e os orang utans ("homens da selva", de acordo com o idioma malaio). Esses mitos também explicam a afinidade de Tarzan, o rei dos macacos, e Mogli, o menino-lobo, com as criaturas da selva. No que diz respeito aos nossos índios, alguns exploradores se encantaram com os hábitos dos "americanos", mas o modo de vida e o suposto apetite por carne humana levaram muitos a acreditarem que os índios deveriam ser escravizados ou exterminados, pois não eram humanos.

Essas idéias predominaram entre os rudes e incultos exploradores, de modo que o papa Paulo III promulgou uma bula (Sublimis Dei, 2 de Julho de 1537) estabelecendo que os índios eram seres humanos e deveriam ser expostos às Sagradas Escrituras. Até o "pai da independência" do Brasil, José Bonifácio, tinha um conceito nada lisonjeiro em relação aos nativos: eles eram apáticos, preguiçosos, melancólicos e tais vícios eram os resultados da amamentação prolongada dos indiozinhos - "não é muito fora de propósito o que alguns dizem, que entre o índio e o europeu do meio e norte da Europa há a mesma diferença que entre os índios e os monos grandes".

Ora os índios são seres perfeitos, ora são criaturas bestiais. Essas flutuações de julgamento também se manifestam em relação à floresta amazônica: o Éden tropical se transformou no "Inferno Verde", mas hoje éo pulmão do mundo. A tese do embaixador Afonso Arinos de Melo Franco (1905-90) é ousada e atraente, mas não convence. Ela foi formulada durante a sua estada num sanatório suíço, quando ele buscava a cura de uma tuberculose, e veio à lume em 1937. A segunda edição surgiu em 1976, a terceira em 2007. 
O embaixador postulou que o modo de vida dos nossos índios inspirou o pensamento humanista de Thomas More, Erasmus, Montaigne, John Locke e culminou na bondade natural do homem selvagem, tese defendida por Jean Jacques Rousseau e que foi a fundamentação intelectual para a Revolução Francesa (1789). O livro é um ensaio inteligente, mas não tem consistência. A valorização do modo de vida natural (i.e., próximo e em íntimo contato com a natureza) é um fenômeno mais antigo, como pode ser visto no mito de Arcádia ou das crianças que viviam entre as feras; muitos contemporâneos de Montaigne e Rousseau não estavam plenamente convencidos de que os índios descendiam de uma linhagem direta dos primeiros habitantes do Éden.

As idéias acerca dos nativos eram baseadas nos relatos dos antigos exploradores. Esses relatos não eram confiáveis, pois uns plagiavam aos outros ou descreviam coisas inimagináveis, como os gigantes patagões (mais de $3 \mathrm{~m}$ de altura, origem do nome "terra da Patagônia"), as fortes e alvíssimas amazonas, aves monstruosas que devoravam um boi inteiro e, é claro, os inúmeros canibais. Os diários de viagens eram largamente apreciados nos séculos XVI e XVII e inspiraram autores de verve satírica, como Jonathan Swift ("As viagens de Gulliver", 1726) e o barão de Münchhausen. Voltaire também achava graça dessas idéias e escreveu textos interessantes sobre a suposta bondade natural dos selvagens. No Brasil, esses delírios da imaginação foram combatidos por Monteiro Lobato - ele formulou um conceito para explicar o fenômeno: "indianismo balsâmico".

Os prefaciadores de "O índio brasileiro e a Revolução Francesa", amigos do jurista Melo Franco, se queixaram do pouco caso da comunidade científica em relação à obra, embora algumas idéias do livro tivessem sido apropriadas por outros investigadores, sem a devida citação da fonte. Isso é grave. Um outro prefaciador anunciou que gradativamente a obra vêm ganhando feições de obra clássica; outro apontou que o ilustre autor havia entrado definitivamente na literatura mundial, vaticinando que a sua obra seria algo equivalente a um salto paradigmático. Entre o pouco caso da comunidade cientifica e o status de obra clássica, infelizmente o livro permaneceu praticamente ignorado desde a primeira edição (1937). O ensaio de Melo Franco deveria despertar algum interesse entre os franceses, pois ele analisa os fatores que antecederam a um importante episódio da história da França, mas a obra não recebeu sequer uma edição em francês. Culpa de quem? O prefaciador julga que isso é uma falha do Itamaraty. 